\title{
The Quality of Ornamental Japanese Carp (Cyprinus carpio var. Koi) After Electroporation as a Gene Material Transfer Method
}

\author{
Sa'idah Luthfiyah $^{{ }^{1}}{ }^{*}$, Agoes Soeprijanto ${ }^{2}$, Yuni Kilawati ${ }^{2}$ \\ ${ }^{1}$ Master Program, Faculty of Fisheries and Marine Sciences, University of Brawijaya, Malang, Indonesia \\ ${ }^{2}$ Faculty of Fisheries and Marine Sciences, University of Brawijaya, Malang, Indonesia
}

\begin{abstract}
Spermatozoa are male gametes that have an advantage in acting as gene transfer media (SMGT), because in transferring genetic material, sperm uses relatively natural vectors. This study was conducted to know sperm quality of Koi after short electroporation with different voltages using Gene Pulser. The study was conducted using a complete randomized design (RAL) with three (3) replications and five (5) treatments, namely: $10 \mathrm{~V} . \mathrm{cm}^{-1}, 20 \mathrm{~V} . \mathrm{cm}^{-1}, 30 \mathrm{~V} . \mathrm{cm}^{-1}, 40$ V. $\mathrm{cm}^{-1}$, and 1 control. Electroporation was done with square wave, $1 \mathrm{~ms}$ duration of electroporation, 4 times of electroporation shocks with $0.1 \mathrm{~s}$ duration. The results showed that electroporation with different voltage levels significantly affected the motility and viability of sperm. Based on orthogonal polynomial analysis, it was known that the treatment affected motility and viability of sperm with a linear equation $y=-0.9 x+5,4 R^{2}=0.920$ and $r=0.96$ for motility and $y=-11.26 x+91.61 R^{2}=0.823$ and $r=0.91$ for viability, meaning that the higher the level of electroporation the lower the viability and sperm motility produced. From the results of this study, it can be suggested that the electroporation of Koi sperm as a gene transfer medium should be performed at a voltage of $10 \mathrm{~V} . \mathrm{cm}^{-1}$.
\end{abstract}

Keywords: electroporation, Koi, sperm quality, transgenesis.

\section{INTRODUCTION}

Spermatozoa are male gametes that have an advantage in acting as gene transfer media, because in transferring genetic material, sperm uses relatively natural vectors [1]. Sperm cells have been used as gene transfer vectors in fish where the entry of gene construction into sperm can be facilitated by the use of electroporator [2].

Electroporation is a method of gene transfer by using a series of short electrical vibrations to temporarily dissolve the cell membrane, thereby the foreign DNA molecule can enter the cell and interact to integrate it with the genome of the test cell and can be expressed on the next organism $[3,4,5]$. The integration of DNA into sperm depends on the electrical voltage, the amount of shock imposed, and the concentration of the DNA. The efficiency of DNA transfer, with the electrophoresed sperm media, is influenced strongly by stress and shock duration [6]. The use of electroporation method facilitates the formation of temporal pores on the surface of the target cell membrane so foreign DNA can enter the cell [7].

\footnotetext{
* Correspondence author:

Sa'idah Luthfiyah

Email : luthfiyahsaidah.salut@gmail.com

Address : Faculty of Fisheries and Marine Sciences, University of Brawijaya, Veteran Malang, 65145
}

The application of transgenesis technology to Koi using electroporation method in fish sperm as the gene transfer medium has not been done in Indonesia. The development of fish transgenesis in Indonesia during this decade mostly done by applying microinjection method (such as Carp, grouper, catfish, stripped catfish) $[8,9]$. The use of microinjection methods are inefficient because it requires special expertise to apply, takes a long time, and expensive. Recently, transgenesis development for aquatic animal is better to be transferred using electroporation method, because electroporation considered more suitable for the aquaculture and does not require special skills [8]. That is also seen in the efficacy of succesful gene transfer using sperm elctroporation method that has been reported to have higher efficiency compared with microinjection method, as shown in ayu fish (Plecogosus altivelis) the successful of gene transfer is $55 \%$, in zebrafish and moad loach are $80 \%$, in indian gold fish $25 \%$, and $85,75 \%$ in stripped catfish $[10,11,12]$.

Therefore, to know the succesful of using gene transfer method with sperm electroporation especially for Koi, it is necessary to do the experiment about preliminary study on sperm quality after giving electric shock. A preliminary study on the sperm quality of Koi fish after electroporation is important to determine the ability of sperm to fertilize egg. So, it is necessary to experiment with different stress levels 
to get the optimal stress levels [6]. The efficiency of DNA transfer, with the electrophoresed sperm media, is influenced strongly by stress and shock duration. The purpose of this study was to determine the effect of stress on sperm quality.

\section{MATERIALS AND METHODS}

This study has been conducted at Central Laboratory of Life Sciences (LSIH) - and Breeding and Reproduction Laboratory, Faculty of Fisheries and Marine Science University of Brawijaya Malang. The equipment used in this research was 1 set of BIO-RAD Gene PulserXcell ${ }^{\mathrm{TM}}$ device consisting of electroporator, shock pod, and cuvette machine, Olympus BX 51 microscope of Inverted type, Olympus CX21 binocular microscope, scales, ruler, petri dish, plastic bowl, $1 \mathrm{ml}$ syringe, aquarium, pond, napkin, microtube $1.5 \mathrm{ml}$ and 1 $\mathrm{ml}$, micropipette, pipette, yellow and white tip, non-EDTA vacum tube, digital camera, object glass, cover glass, thermometer, handtally counter, haemocytometer, and aerator and its installation.

The materials needed were mature Koi ( $C y$ prinus carpio var. Koi), Ringer Lactat (RL), eosin negrosin, tissue, cotton, alcohol $70 \%$, alumunium foil, and aquadest, ice gell pack. The experimental design used was Completely Randomized Design (CRD) with five (5) treatments and three (3) replications with the following treatment. The research parameters were sperm quality (motility and viability) of Koi.

$K=$ without electric shock

$A=$ with electric shock at 10 volt

$B=$ with electric shock at 20 volt

$\mathrm{C}=$ with electric shock at 30 volt

$\mathrm{D}=$ with electric shock at 40 volt

\section{Data Collection \\ Collection of Sperm (Milt)}

The sperm collection is obtained by massaging the matured male Koi fish (stripping) from the abdominal direction to the urogenital hole, and the sperm was put in the $3 \mathrm{~mL}$ syringe. The sperm was diluted using a ringer lactate (RL) solution of 1:9 $[13,14]$ The diluted sperm was then stored on a non-EDTA Vacum tube coated with aluminum foil and placed on ice gell [15].

\section{Sperm Electroporation}

Sperm electroporation was done by using Gene Pulser II machine (BIO-RAD, USA). The diluted sperm collection was taken as much as 25 $\mu \mathrm{l}$ and was inserted into cuvette $0.2 \mathrm{~mm}$ and electroporated using square wave type, $1 \mathrm{~ms}$ pulse length, 4 times shock number and $0.1 \mathrm{~s}$ duration [16].

Sperm that had been given a shock was added with a solution of ringer lactate in cuvette as much as $275 \mu$ l. After that, the sperm was poured into $1.5 \mathrm{ml}$ micro tube as much as $5 \mu \mathrm{l}$ for sperm quality observation (motility and viability) and $270 \mu \mathrm{l}$ for fertilization. Motility of sperm were observed using an inverted microscope and viability of sperm were observed using a binocular microscopy (Olympus CX21), and sperm concentrations were calculated using a haemocytometer $[16,17]$.

\section{Sperm Motility}

Observation of sperm motility was performed by hanging drop method [18] by dripping $1 \mu l$ of sperm on a glass object mixed with $5 \mu$ of distilled water. Then, sperm motion was observed after exposure to water by seeing the number of progressive sperms using inverted microscope with 1000x magnification. The criterion of movement intensity was observed based on Dewi [19], which mapped sperm motility assessment criteria by scoring method (Table 1).

Table 1.Criteria on Assessment of spermatozoa Motility

\begin{tabular}{lc}
\hline \multicolumn{1}{c}{ Criteria } & Score \\
\hline $\begin{array}{l}\text { 70\% of spermatozoa move forward quickly } \\
\text { with varied tail movements }\end{array}$ & 5.0 \\
$55-70 \%$ of spermatozoa move forward, & 4.0 \\
many show quick movement & \\
$\begin{array}{l}40-55 \% \text { of spermatozoa move forward, } \\
\text { some show quick movement }\end{array}$ & 3.0 \\
$25-40 \%$ of spermatozoa move forward & 2.0 \\
$10-25 \%$ of spermatozoa move forward & 1.0 \\
$1-10 \%$ of spermatozoa move forward, & 0.5 \\
mostly do not make any movement & \\
All spermatozoa show no movement & 0.0 \\
\hline
\end{tabular}

\section{Sperm Viability}

Sperm viability was calculated in order to find out the percentage of surviving sperm. The percentage of sperm viability can be calculated by the following formula [20]:

$$
\% \text { viability }=\frac{\sum \text { Surviving sperm }}{200} \times 100 \%
$$

\section{Data Analysis}

The data was analyzed statistically by using diversity analysis (ANOVA), in accordance with the design used, i.e. Completely Randomized Design (CRD). If the variance data showed that the treatment brought significant or highly significant, then to compare the value between treat- 
ments were done by the Smallest Real Difference (SRD) test and regression analysis.

\section{RESULT AND DISCUSSION}

\section{Sperm Quality of Koi}

Sperm quality before treatment can be seen in Table 2. Table 2 indicates that sperm used in the study was in good quality. Dacie and Lewis [21] and Rustidja [3] has found that fish sperm concentration ranges from \pm 3.7 to $11.9 \times 10^{9}$ spermatozoa $\mathrm{mL}^{-1}$ liquid, as fish to produce eggs to hundreds of thousands, in addition to high concentration, will require more sperm volume. The large number of sperm that can be stripping from a male koi depends on the age, size, and frequency of sperm discharge [3].

Tabel 2. Sperm Quality before Treatment

\begin{tabular}{ll}
\hline Parameter & Result \\
\hline Concentration & $11.7 \times 10^{9}$ cell. $\mathrm{mL}^{-1}$ \\
$\mathrm{pH}$ & 7 \\
Volume & $1.8 \mathrm{~mL}$ \\
Head diameter & $\pm 3 \mu \mathrm{m}$ \\
Length of tail & $\pm 8 \mu \mathrm{m}$ \\
Motility & $90 \%$ \\
Intensity movement & $5(+++)$ \\
Viability & $98.67 \%$ \\
\hline
\end{tabular}

\section{Quality of Sperm Post-Electroporation Sperm Motility}

The result of sperm motility observation after treatment showed a decrease of quality compared with before treatment. The highest motility score post treatment was on treatment of 10 V.cm ${ }^{-1}$, while the lowest was on $40 \mathrm{~V} . \mathrm{cm}^{-1}$. The details can be seen in Table 3 .

Table3. Motility and Viability of Koi spermatozoa postelectroporation

\begin{tabular}{ccc}
\hline \multicolumn{3}{c}{ electroporation } \\
\hline $\begin{array}{c}\text { Voltage } \\
\text { (V.cm }\end{array}$ & Motility (Score) & Viability (\%) \\
\hline Control (0) & 4 & 73.67 \\
10 & 4 & 69.46 \\
20 & 3 & 67.34 \\
30 & 2 & 53.05 \\
40 & 0.5 & 25.54 \\
\hline
\end{tabular}

In the analysis of variance, it is known that electric shock treatment (electroporation) with different electric field strength gives a very significant effect on the sperm motility value on each treatment (Table 4).

Therefore, $\mathrm{H}_{0}$ is rejected and $\mathrm{H}_{1}$ is accepted, and continued with Smallest Real Difference (SRD) test and regression analysis. From the result of Smallest Real Difference (SRD) test and regression analysis, it is known that the higher the electric field strength $\left(\mathrm{V} . \mathrm{cm}^{-1}\right)$ given to the sperm, the motility value decreased to only 0.5 on the treatment of $40 \mathrm{~V} . \mathrm{cm}^{-1}$ (Fig. 1).

Table 4.Variance Table

\begin{tabular}{lllllll}
\hline $\begin{array}{l}\text { Source of } \\
\text { Variance }\end{array}$ & df & SS & MS & F & F 5\% & F 1\% \\
\hline Treatment & 4 & 34.27 & 8.57 & 39.54 & 3.48 & 5.99 \\
Random & 10 & 2.17 & 0.22 & $* *$ & & \\
Total & 14 & & & & & \\
\hline \multicolumn{7}{c}{$*$ highly significant }
\end{tabular}

Sperm in motility condition (low movement) still holds the possibility to fertilize because. The slow progressive of spermatozoa still able penetrate the microphile hole [22].

Fertilization may occur when the distance between the spermatozoa and the egg is very close. Spermatozoa of the sperm on low motility condition have small ability to perform fertilization that is only about $10 \%$ [23]. This is also reinforced by previous study which states that in general sperm that have been electrophorated is still able to fertilize because sperm given electric shock does not show any damage [24]; the sperm cell becomes smaller (dwarf cells) [22].

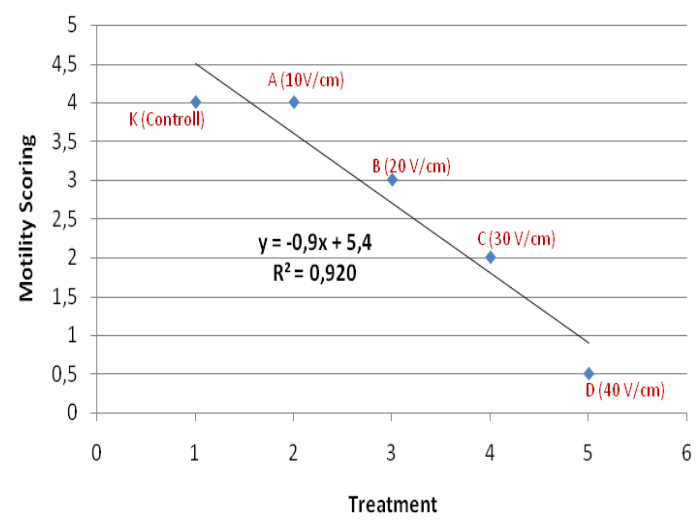

Figure 1. Sperm motility post-electroporation

\section{Sperm Viability}

Viability of sperm is one important sperm quality indicator, because the value of sperm viability represents the percentage of surviving sperm after treatment. Results from observations of sperm viability (Table 2) showed that the highest sperm survival rate was in treatment B (10 V.cm ${ }^{-1}$ ) and decreased with increasing of electric field strength given to sperm.

The result of the analysis of the variance also shows that the electric shock (electroporation) with different electric field strengths gives a very real effect because the F-count value $>$ of F-table, i.e. $5 \%$ and $1 \%$ (Table 5). Thus, the statistical calculation continued with orthogonal polynomial 
test and from the test results, it is seen that the higher the electric field strength given when electroporation takes place further decreases the survival rate of post-treatment sperm (Fig. 2).

Table 5.Variance Table on Viability

\begin{tabular}{lllllll}
\hline $\begin{array}{l}\text { Source of } \\
\text { Variance }\end{array}$ & df & SS & MS & F & F 5\% & F 1\% \\
\hline Treatment & 4 & 4625.85 & 1156.46 & 77.88 & 3.48 & 5.99 \\
Random & 10 & 148.50 & 14.85 & $* *$ & & \\
Total & 14 & & & & & \\
\hline \multicolumn{7}{c}{$* *$ highly significant }
\end{tabular}

The decrease in viability in most treatments (Fig. 2) occurs because the electric field stresses given to the sperm can cause the opening of pores that are too wide and fail to close as before, which can lead to damaged or broken cells and this triggers damage to the membrane [24]. This is confirmed by Jeyendran [25] which explained that the permeability of spermatozoa membrane is closely related to the viability of spermatozoa because, as it is known, membrane permeability is closely related to the transport of essential nutrients in cell metabolism.

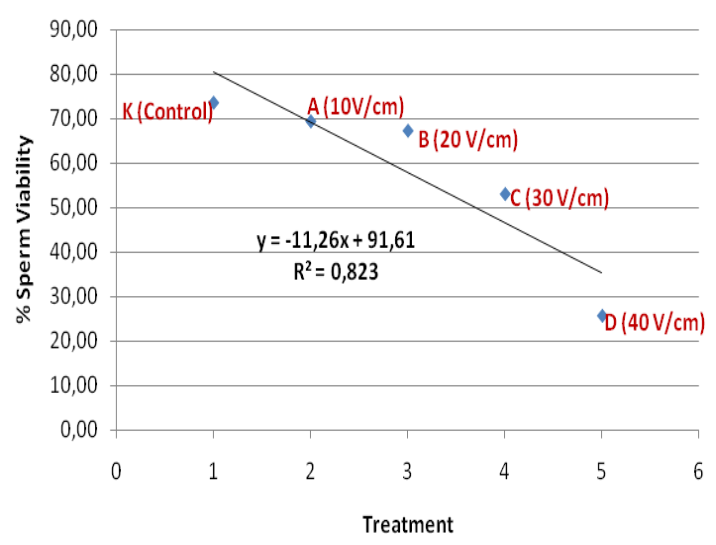

Figure2. Sperm viability post-electroporation

The treatment with a voltage of $40 \mathrm{~V} . \mathrm{cm}^{-1}$ has the lowest viability value. This is because there is an increase in temperature on the sperm when given the voltage-possible because at the time of cooling with ice, cuvette does not perform well. The sample resistance can be increased by reducing the sample temperature, reducing the ion content on diluent, reducing fluid volume in the cuvette in the case of medium with low resistance [26]. Thus, if the sperm (sample) contains many ions then the resistance of the sample increases so it needs longer timefor pulse lengthso the temperature will increase and cause the sperm to die. This is also supported by previous studies which states that the survival (viability) of spermatozoa is strongly influenced by temperature and sperm will generally live longer in low temperatures $[3,18]$.

Based on the observation of motility and viability on post electroporation sperm, it is known that the increase of voltage (electric voltage) given at the time of sperm electroporation affects the decrease in the intensity of movement and ability of sperm to survive. It can be seen from the observation result $\mathrm{E}\left(40 \mathrm{~V} . \mathrm{cm}^{-1}\right)$, where the value of motility score was only 0.5 and viability was $25.4 \%$. That is because electroporation of sperm gives a very real effect on the biological and physiological conditions of sperm cells. This happens because an excessive electric shock can cause the sperm cell to lose its elastic properties and damage its channel membrane if it exceeds the critical point of its elasticity and can damage the membrane causing the sperm tail to break. Therefore, in the activity of gene transfer using electroporation method, optimization is necessary to know the ability of sperm in becoming gene transfer vector.

The ability of the sperm cell to with stand the given electric shock is influenced by several factors such as the type of fish, the quality of the sperm before the treatment as well as some of the electroporation parameters themselves (voltage, shock number, shock length, shock interval, and wave type used). This is in accordance with the opinion of Knight and Scrutton [27] which explained that electroporation is the process of modifying the permeability of cell membranes through electric field strength.

The application of electric shock to the cell suspension induces the polarization of the cell membrane component and develops a voltage potential across the membrane. When the potential differences between the inside and outside of the cell membrane passes through the critical point, the membrane component is reorganized into the pores in the localized area, and the cell becomes permeable to the entry of macromolecules [28]. The magnitude of pore size change is influenced by electric field strength, duration of shock, and ionic strength of the media. This permeability change is temporary, provided the electric shock does not exceed the critical limit for cells [29].

\section{CONCLUSION}

The provision of electrical shock has a significant effect on the motility and viability of sperm, in which the increasing of electric voltage can decrease motility rate and viability of sperm of 
koi fish (Cyprinus carpio var. Koi). We recommend electroporation of Koi fish sperm (Cyprinus carpio var. Koi) as a gene transfer medium should be performed at a voltage of $10 \mathrm{Vcm}^{-1}$ with four (4) numbers of shocks and 1 ms shock duration.

\section{REFERENCES}

[1] Lavitrano, M., M. Busnelli, M.G. Cerrito, R. Giovannoni, S. Manzini, A. Vargiolu. 2006. Sperm mediated gene transfer. Reprod. Fertil. Dev. 18(1-2). 19-23.

[2] Muller, F., Z. Ivich, F. Erdelyi, T. Papp, L. Varadi, L. Horvart, N. Maclean. 1992. Introducing foreign gene into fish eggs with electroporated sperm as carrier. Mol. Biol. Biotechnol. 1. 276-281.

[3] Rustidja. 2000. Prospek pembekuan sperma. Faculty of Fisheries and Marine Sciences. University of Brawijaya. Malang.

[4] André, F.M., J. Gehl, G. Sersa, V. Préat, P. Hojman, J. Eriksen, M. Golzio, M. Cemazar, N. Pavselj, M.P. Rols, D. Miklavcic, E. Neumann, J. Teissié, L.M. Mir. 2008. Efficiency of high- and low-voltage pulse combinations for gene electrotransfer in muscle, liver, tumor and skin. Hum. Gene Ther. 19(11). 1261-1272.

[5] Nakamura, H (Ed). 2009. Electroporation and Sonoporation in developmental biology. Springer. Japan.

[6] Symond, J.E., S.P. Walker, F.Y.T. Sin. 1994. Electroporation of salmon sperm with plasmid DNA; evidence of enchanned sperm/DNA assosition. Aquaculture. 199. 313-327.

[7] Samarsik, A., G. Warr, T.T. Chen. 2002. Production transgenik fish with elevated levels of innet devense activity to bacterial pathogen. Mar. Biotech. 4. 310-322.

[8] Alimuddin., L.I. Purwanti, M.H.F. Ath-thar, C. Muluk, O. Carman, K. Sumantadinata. 2009. Aktivitas promoter â-aktin Ikan Medaka Jepang (Oryzias latipes) pada Ikan Mas (Cyprinus carpio). Jurnal Natur Indonesia. 11(2). 70-77.

[9] Subyakto, S., Alimuddin, Rustidja, M.S. Djati, I. Faizal, R.S. Aliah, G. Astutik, K. Sumantadinata. Comparison of three different techniques of gene transfer in Humpback Grouper (Cromileptes altivelis). Biotropia. 18(1). 13-23.

[10] Buwono, I.D., M.U.K. Agung, U. Subhan. 2016. Perakitan Ikan Lele (Clarias sp.) transgenik dengan teknik elektroporasi sperma. Jurnal Biologi. 20(1). 17-28.
[11] Tsai, H.J. 2000. Electroporated sperm mediation of a gene transfer system for Finfish and Shellfish. Mol. Reprod. Dev. 56. 281284.

[12] Zhang, P.J., M. Hayat, C. Joyce, L.I. GonzalezVillasenor, Lin CM, Dunham RA, Chen TT, Powers DA. Gene transfer, expression and inheritance of pRSV-rainbow trout-GH cDNA in the common carp, cyprinus carpio (Linnaeus). Mol Reprod Dev, 1990, 25: 3-13.

[13] Billard, R., J. Cosson, S.B. Noveiri, M. Pourkazemi. 2004. Cryopreservation and short-term storage of sturgeon sperm, a review. Aquaculture. 236. 1-9.

[14] Rahardijanto, A., Abdulgani, N. Trisyani 2012. Pengaruh konsentrasi larutan madu dalam $\mathrm{NaCl}$ fisiologis terhadap viabilitas dan motilitas spermatozoa Ikan Patin (Pangasius pangasius) selama masa penyimpanan. Jurnal Sains dan Seni ITS. 1(1). E58-E63.

[15] Wijayanti, G.E., S.B.I. Simanjuntak. 2006. Viabilitas sperma Ikan Nilem (Osteochilus hasselti C.V) setelah penyimpanan jangka pendek dalam larutan ringer. J. Fish. Sci. 7(2). 207-214.

[16] Anitasari, S., A. Soeprijanto, A.R. Faqih. 2015. The effectiveness of hrGFP Gene Reporter role in Carp Fish (Cyprinus carpio) transgenesis process based on convocal microscopy analysis. J. Exp. Life Sci. 5(2). 8288.

[17] Indriani. 2013. Daya hidup spermatozoa Sapi Limousin yang dipreservasi dengan metode Water Jacket dan Free Water Jacket. Jurnal Veteriner. 14(3). 379-386.

[18] Toelihere, M.R. 1985. Inseminasi buatan pada ternak. Angkasa. Bandung

[19] Dewi, R.R.S.P.S. 2010. Studi over-ekspresi gen penyandi hormon pertumbuhan melalui elektroforesis sperma untuk membuat ikan patin siam transgenik cepat tumbuh. Disertasi.InstitutPertanian Bogor. Bogor,

[20] Susilowati, T. 2011. Spermatology. University of Brawijaya. UB Press. Malang.

[21] Dacie, J.V., S.M. Lewis. 1984. Practical haematology. Churchill Livingstone. London.

[22] Hidayaturrahmah. 2007. Waktu motilitas dan viabilitas spermatozoa Ikan Mas (Cyprinus carpio L.) pada beberapa konsentrasi larutan fruktosa. Department of Biology. Lambung Mangkurat University. Banjarmasin. Available at: http://www. unlam.ac.id/bioscientiae.

[23] Sucipto, A. 2008. Petunjuk teknis gynogenesis pada Ikan Mas. Available at: 
http://naksara.net/Aquaculture/Genetic/Pa ge-3.html.

[24] Sin, F.Y.T., U.K. Mukherjee, J.C. McKenzie, I.L. Sin. 1995. Abalone sperm-DNA interaction. In: Proceedings of International Symposium on Biotechnology Applications in Aquaculture. National Taiwan University. 95-99.

[25] Jeyendran R.S., H.H. van der Ven, M. PerezPelaez, B.G. Crabo, L.J.D. Zaneveld. 1986. Development of an assay to assess the functional integrity of the human sperm membrane and its relationship to the other semen characteristics. J. Reprod Fertil. 70. 219-228.

[26] BIO-RAD. 2006. Gene Pulser Xcell Electroporation System. Instruction manual. BIO-RAD. Available at: http://www.biorad.com/webroot/web/pdf/lsr/literature/40 06217A.pdf.

[27] Knight, D.E., M.C. Scrutton. 1986. Gaining access to the cytosol: the technique and some application of electropermeabilization. Biochem. J. 234. 497-506.

[28] Faridah, N. 2012. Introduksi dan ekspresi gen hormon pertumbuhan pada Ikan Mas transgenik. Master Thesis. Graduate School, Master Program of Aquaculture, Bogor Agricultural University. Bogor.

[29] Tsong, T.Y. 1983. Voltage modulation of membrane permeability and energy utilization in cells. Biosci. Rep. 3(6). 487-505. 